\title{
The Dedication of English Educator's Career in Inspiring Language Skills among the Engineering Pupils
}

\author{
S. Rajkumar, A. G. Vadivelan
}

\begin{abstract}
Communication infers the interchange of musings and thoughts with the aim of passing the information from the sender to receiver. In this 21 st century era, procuring fundamental skills of communication has turned out to be basic for individual and expert development and achievement. Consequently, a student of Engineering and Technology can't bear to overlook the basics of communication. In the worldwide senerio, pupils of Engineering and Technology are in need of language skills for their prosperity both in the avenue of Education and Career. Fluency in the skill of communication is a basic needful to climb on the professional bureaucracy. Having this as a primary concern, the English language instructor needs to assume a critical part by assuming a liability to support the pupils in building up their skills in communication. This research paper endeavours to feature the indispensable prominent part of the English language tutor in building up the vital skills to survive.
\end{abstract}

Keywords: Communication Skill, Innovation, LSRW, Technical English.

\section{INTRODUCTION}

Powerful Communication is tied in with passing on messages to other individuals unmistakably and unambiguously with as meagre twisting as could be allowed. For an effective life of movement, the communication skills have become more essential. Present associations are continually looking for the applicants who sounds good at communication skills notwithstanding great specialized learning. The individuals who can't impart well will miss out; they get considerably less kudos for their accomplishments than they merit. Along these lines, effective communication is an absolute necessity to impact individuals to win their hearts. Unfortunately many Engineering pupils don't have these required abilities and subsequently they fail to get good offers or good employments in the renowned $\mathrm{MNC}^{\mathrm{e}} \mathrm{s}$. Because of these issues, the tutor who instructs English language ought to give the most significance to the enhancement of English communication. Presently we may put forward some

suggestions how an English tutor can be an innovative and fruitful in educating diverse portions of communication.

Revised Manuscript Received on December 24, 2019.

* Correspondence Author

Mr. S. Rajkumar, English department, Kalasalingam Academy of Research and Education, Krishnankoil, Tamil Nadu, India. s. rajkumar@klu.ac.in

Dr. A. G. Vadivelan, English department, Kalasalingam Academy of Research and Education, Krishnankoil, Tamil Nadu, India. vadivelanag@gmail.com

\section{THE RESPONSIBILITY OF ENGLISH LANGUAGE TUTOR:}

The most significant role that the instructors of English have to help the pupils in defeating their feelings of trepidation about communication and boost them to grow more positive impression on communication oriented activities. He has to assume the roles, for example, - guide, helper, communication skills trainer and so on. The English language educators should likewise know about the most recent innovations, techniques and methodologies of language instructing, investigate new thoughts and have a specific measure of specialism in the concerned subject.

\section{A. Educating Of Listening Skills To The Pupils Of Engineering And Technology :}

Listening is regularly a dismissed aptitude. There is a decent saying in English. "One can't turn into a decent correspondence except if one is a decent audience". Along these lines, the instructors of English should make pupils to acknowledge one vital thing i.e., to end up successful communicator, pupils should become great audience first. Similarly as a kid figures out how to talk subsequent to tuning in to his nearby ones, so do the individuals who take in another dialect. The aim of the educator is to pull the students to do the best of their abilities. In order to improve the listening skills among the students the teacher has to make use the language labs. Logical progressions have delivered various creative items to help the learning procedure.

In Every day before starting the subject class, bring a magazine or articles to the class and read loudly the printed content and ask a couple of questions and request that pupils to compose their answers on the sheet of paper. In the wake of allowing a couple of minute's time again inquires as to whether anybody knew the responses to the majority of the questions. It is improbable that any one individual will have addressed the greater part of the questions effectively. Ask the students to find out the reason for not getting proper response. Examine how they could enhance their listening skill and give steps for better improvement.

\section{B. Educating Of Speaking Skills To Engineering Students:}

Talking, in English is an essential piece of the dialect. Be that as it may, recently, not only the engineering and technology students but also the other streams of pupils are unable to talk in English since they are at hesitation and panic. The instructor should act as the hero and propel to the understudies for beating this dread as fast as could reasonably be expected. 
The greater parts of the pupils think that it is hard to pass on their considerations, on account of a solid impact of their territorial dialect and primary language. With a specific end goal to defeat this specific issue in the understudy network, the prominent English tutor ought to first impact the understudies to sense at home while he makes the pupils to talk in English.

The language tutor can adjust a student- focused way to deal with educating. Along these lines, the pupil is made to talk more often than not and abundant open doors ought to be made for the pupils to utilize English in the school as well as outside of it. Continuous output to the dialect will end up being advantageous. Most importantly, the educator ought to support the pupils of Engineering and Technology by requesting that they attempt to end up not so much reluctant but rather more sure while they are talking with somebody. Pupils ought to be continually persuaded to talk in English instead of in their primary language.

Through the effective discussion, the educator has the chance to hone the pupil's relational abilities. Research proposes that discussion energizes distinctive kinds of reactions, assist pupils with developing persuading contentions, and enables educators and pupils to gain from each other. Moreover, The tutor can also arrange mock interviews, oral introductions to enhance the relational abilities of the students.

\section{Educating Of Reading Skills To The Pupils Of Engineering And Technology:}

Nowadays, Reading skills are presumably the most imperative dialect abilities essential for scholastic and expert intentions. Comprehension in reading indicates to the ID of the focal topic, principle thoughts, supporting subtle elements, and composing designs. Francis Bacon properly stated, "Reading makes a man complete". It enables a pupil to enhance his vocabulary, builds up the appreciation capacity and expands the dialect style. Subsequently, the instructor should think about this and help the understudy ace the aptitudes of reading.To solve this, the English educator must provide a couple of Reading comprehensions as stories, depictions and portrayals. The students can be urged by enabling them to take after the diverse strategies for reading, for example, skimming and scanning. By doing this, make the students select difficult words to find out the appropriateness of particular context. With the help of this, the students can understand the words and enrich their vocabulary.

Visual recognition abilities can be improved in order to become an effective reader. Visual discernment is a basic thing to read properly because we get a word through sight. Off base visual recognition may prompt visual misconstruing and absence of cognizance. It might likewise prompt disarray and misconstruing. The English dialect educator should urge his pupils to build up their visual recognition skills.

\section{Educating Of Writing Skills To The Pupils Of Engineering And Technology :}

Francis Bacon suggested that "Writing makes a man exact". The instructor does not neglect the students to educate them the art of composing.. Anyway, written work is the toughest job if the learner does not possess any
interest.The English educator can enhance the written skill with the help of language laboratory.Writing can be honed through activities like preparing reports, resumes and letters. The language tutor can make the pupils to write article on current events, place, festivals or important places. Organize writing workshops on letter, report, resume, notice and give input to the students This is the snappiest approaches to enhance composing. In this procedure, the dialect instructor has to bring up the blunders and furthermore help the learners on rectifying the defects. The educator ought to also direct the pupils to make an involvement to take an attempt at better written work every day.

\section{CONCLUSION}

Recently, Instructing the students to improve their LSRW skills is a cheallenging one. Among these communication skill can be enriched only through projects and trainings. It needs relentless endeavours. Because of the uncommon significance given to communication skills, it has turned out to be basic with respect to understudies to ace them. As instructors of English, it is mandatory to enable the learners to build the bewildering power of the English dialect and it is our obligation to assume an essential part in building up the significant four skills of English language among the pupils of Engineering and Technology.

Pics of current interest.

Authors should consider the following points:

1) Technical papers submitted for publication must advance the state of knowledge and must cite relevant prior work.

2) The length of a submitted paper should be commensurate with the importance, or appropriate to the complexity, of the work. For example, an obvious extension of previously published work might not be appropriate for publication or might be adequately treated in just a few pages.

3) Authors must convince both peer reviewers and the editors of the scientific and technical merit of a paper; the standards of proof are higher when extraordinary or unexpected results are reported.

4) Because replication is required for scientific progress, papers submitted for publication must provide sufficient information to allow readers to perform similar experiments or calculations and use the reported results. Although not everything need be disclosed, a paper must contain new, useable, and fully described information. For example, a specimen's chemical composition need not be reported if the main purpose of a paper is to introduce a new measurement technique. Authors should expect to be challenged by reviewers if the results are not supported by adequate data and critical details.

\section{REFERENCES}

1. G. O. Young, Barun K.Mitra. Effective Technical Communication: A Guide for Scientists and Engineers. Oxford University Press India, 2006

2. Brumfit, C.J. Problems and Principles in English Teaching. U.K Pergamon Inst. of English, 1986. 
3. John. W. Davies. Communication Skills: A Guide for Engineering and Applied Science Students. Prentice Hall of Australia Ply Limited, 2001.

4. Marc J. Riemer. Communication Skills for the $21^{\text {st }}$ Century Engineer. Global Journal of Engng.Educ., Vol.11, No.1. Published in Australia. 2007.

5. M Ashraf Rizvi. Effective Technical Communication. Tata McGraw-Hill Education, 2005.

6. Richard Ellis. Communication Skills: Step ladders to success for professionals. Intellect Books, Chicago, USA. 2009.

\section{AUTHORS PROFILE}

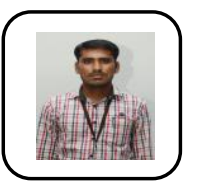

Mr. S. Rajkumar, M.A., M.Phil., graduated at Madurai Kamaraj University, Tamil Nadu, India, presented and published papers at International Conference, won the best teacher award, guided UG projects, working as an Assistant Professor at Kalasalingam Academy of Research and Education, Tamil Nadu, India.

Dr. A. G. Vadivelan, PhD., graduated at Anna University, Tamil Nadu, India, presented and published papers at National and International Conference. Published papers at International Journals. Guided UG, PG Projects and MPhil Dissertation. 